\title{
Serologic evidence of equine granulocytic anaplasmosis in horses from central West Brazil
}

\author{
Evidência sorológica de anaplasmose granulocítica equina em equinos do Centro-oeste Brasil \\ Carlos Augusto Salvagni ; ; Ana Sílvia Dagnone ${ }^{1}$; Tiago Salles Gomes ${ }^{3}$; Jozivaldo Silva Mota²; \\ Gisele Maria Andrade ${ }^{1}$; Cristiane Divan Baldani ${ }^{4}$; Rosangela Zacarias Machado ${ }^{1 *}$
}

${ }^{1}$ Departamento de Patologia Veterinária, Universidade Estadual Paulista - UNESP

${ }^{2} 1$ o Regimento Cavalaria Guarda, Dragóes da Independência

${ }^{3}$ Private DVM

${ }^{4}$ Departamento de Medicina e Cirurgia Veterinária, Universidade Federal Rural do Rio de Janeiro - UFRRJ

Received May 18, 2009

Accepted November 9, 2009

\begin{abstract}
Ehrlichiosis is a zoonotic disease caused by gram-negative and intracellular obligatory bacterial organisms. Equine Granulocytic Anaplasmosis - EGA (formerly Equine Granulocytic Ehrlichiosis, EGE) is a seasonal disease, normally self-limited in horses. There are few reports in Brazil about this ehrlichial agent, as well as its natural vectors. Nowadays, veterinarians are considering the suspicion of EGA in horses with suggestive symptoms of ehrlichiosis and which do not respond to piroplasmosis treatment. The aim of the present study was to identify horses exposed to the agent A. phagocytophilum by serological and molecular techniques. Twenty equine blood and serum samples from the central West region of Brazil were evaluated by microscopic examination of buffy coat smear, enzyme-linked immunosorbent assay (ELISA), indirect fluorescent antibody test (IFAT) and nested polymerase chain reaction (nPCR). Additionally, the serodiagnosis of Theileria equi by IFA and ELISA were carried out, as well as molecular diagnosis by nPCR. Thirteen (65\%) serum samples were positive for $A$. phagocytophilum by ELISA, but none of them were positive by buffy-coat smear examination or nPCR. Antibodies IgG anti-T. equi were detected in $18(90 \%)$ and $17(85 \%)$ horses by IFA and ELISA, respectively and the agent was detected in $9(45 \%)$ animals by nPCR. Our data may be considered as important information to understanding the occurrence of EGA and equine piroplasmosis in central West Brazil.
\end{abstract}

Keywords: Equine granulocytic anaplasmosis, Theileria equi, nPCR, ELISA, IFA.

\section{Resumo}

A Erliquiose é uma doença zoonótica causada por bactérias gram-negativas e intracelulares obrigatórias. A Anaplasmose Granulocítica Equina - AGE (anteriormente denominada Erliquiose Granulocítica Equina, EGE) é uma enfermidade sazonal, normalmente auto-limitante em equinos. No Brasil, existem poucos relatos deste agente erliquial, bem como de seus vetores naturais. Atualmente, veterinários têm levantado a suspeita de casos de AGE em equinos com sinais clínicos sugestivos de erliquiose e náo responsivos ao tratamento para a piroplasmose equina. $\mathrm{O}$ objetivo do presente estudo foi identificar equinos expostos a A. phagocytophilum por meio de técnicas sorológicas e moleculares. Vinte amostras de sangue e soro de equinos da regiáo Centro-oeste do Brasil foram avaliados por meio do exame microscópico de capa leucocitária, ensaio imunoenzimático indireto (ELISA), reação de imunofluorescência indireta (RIFI) e reação em cadeia da polimerase (nested PCR). Adicionalmente, o diagnóstico sorológico de Theileria equi pela RIFI e ELISA foram realizados, assim como o diagnóstico molecular pelo nPCR. Treze (65\%) amostras de soro foram positivas para $A$. phagocytophilum pelo teste de ELISA, entretanto nenhum equino foi positivo pelo exame microscópico da capa leucocitária ou nPCR. Anticorpos IgG anti-T. equi foram detectados em 18 (90\%) e 17 (85\%) equinos pela RIFI e ELISA, respectivamente e o agente foi detectado em 9 (45\%) animais pelo nPCR. Estes dados sugerem importante informação para o entendimento da ocorrência da AGE e piroplasmose equina no Centro-oeste do Brasil.

Palavras-chave: Anaplasmose granulocítica equina, Theileria equi, nPCR, ELISA, IFA.

\footnotetext{
${ }^{*}$ Corresponding author: Rosangela Zacarias Machado Departamento de Patologia Veterinária, FCAV/UNESP,

Universidade Estadual Paulista - UNESP, Campus de Jaboticabal,

Rod. de Acesso Paulo Donato Castellane, s/n, Jaboticabal - SP, Brazil;

e-mail: zacarias@fcav.unesp.br
} 


\section{Introduction}

The Family Anaplasmataceae has four genera - Ehrlichia, Anaplasma, Neorickettsia and Wolbachia - which include small obligatory intracellular bacteria with unique host cell specificities (DUMLER et al., 2001; RIKIHISA, 1991; 2003). Horses can be naturally infected by the ehrlichial agent Anaplasma phagocytophilum (formerly E. equi) causing the Equine Granulocytic Anaplasmosis (EGA) that is a seasonal disease of horses, first reported in 1969 in California (STANNARD et al., 1969; GRIBBLE, 1969). Since then, it has been described worldwide. This agent was found first in humans in 1994 in the United States (BAKKEN et al., 1994) and 16S rRNA gene sequence of $A$. phagocytophilum described in horses and dogs seems to be identical to the A. phagocytophilum strain that infects humans (JOHANSSON et al., 1995) and described in many countries including Chile (LÓPEZ et al., 2003), Italy (RUSCIO; CINCO, 2003) and Korea (HEO et al., 2002). The vectors are Ixodes ticks (PANCHOLI et al., 1995). A. phagocytophilum is presented in various tick-rodent cycles and wild reservoirs in nature (FOLEY et al., 2004). The clinical signs of A. phagocytophilum in horses include high fever, depression, partial anorexia, limboedema, petechiae, icterus, ataxia and a reluctance to move (MADIGAN; GRIBBLE, 1987). However, clinical signs are not specific for the disease and it has been posed that different hosts demonstrate several degrees of susceptibility to regional strains of $A$. phagocytophilum. In South America a few cases of human erlichiosis are described due to E. canis and E. chaffeensis in Venezuela (PEREZ et al., 2006); and serologic evidence of human erlichiosis is found in Chile and Argentina (RIPOLL et al., 1999; LÓPEZ et al., 2003). In Brazil, suspected cases of human were demonstrated with clinical and laboratory findings and with positive serology for human granulocytic anaplasmosis (HGA) by Calic et al. (2004). However, Brazilian spotted fever (BSF) is the most common form of human Rickettsia infection in our country. Ehrlichia chaffeensis was detected for the first time in blood samples from Brazilian marsh deer (Blastocerus dichotomus) captured in the marshes of the Parana River in Southeast Brasil in 1998 (MACHADO et al., 2006), but no human case have been diagnosed to the present time.

Therefore, general diagnosis is based on association of clinical signs in horses, with seasonality and geographic location associated with characteristic gram-negative inclusion bodies/morulae in the cytoplasm of circulating neutrophils in blood smears (MADIGAN, 1993). And the presence of the vector Ixodes ticks is important in the acute phase. The acute phase of the disease can be diagnosed directly by microscopic identification of inclusion bodies in peripheral granulocytes, polymerase chain reaction (PCR) and blood culture (BAKKEN et al., 1994; GOODMAN et al., 1996). PCR methods have been shown to be effective for the diagnosis of acute granulocytic ehrlichial infections (MASSUNG; SLATER, 2003). Antibody detection is also used to support the clinical diagnosis (AGUERO-ROSENFELD et al., 2000). Indirect immunofluorescent antibody assay (IFA) is the most commonly test used in the laboratory to confirm a diagnosis of A. phagocytophilum infection in humans (Human granulocytic ehrlichiosis, HGE). In horses, a diferential diagnostic approach should be made because of such other diseases as encephalitis, liver disease, purpura hemorrhagica, and equine infectious anemia, which can have similar clinical conditions (MADIGAN, 1993). The present study reports the first serologic evidence of granulocytic ehrlichiosis in horses from Brazil. And considering that cases of equine ehrlichiosis can be due to Neorickettsia risticii, a screening PCR for the Genus was performed. Additionally, the serodiagnosis and molecular detection of Theileria equi were carried out once equine piroplasmosis became widespread and a cause of serious concern in Brazil.

\section{Material and Methods}

\section{Horses}

Twenty cases suspected of equine granulocytic ehrlichiosis were selected from horses with clinical signs suggestive of A. phagocytophilum infection. Nineteen mixed-breed horses came from from the Brazilian Army (10 Regimento da Cavalaria de Guarda, Dragóes da Independência, Brasilia - DF, Brazil) and one horse from Goiânia County - GO, Brazil. At the time of initial examination the clinical signs were fever, anorexia, lethargy, pale mucous membranes and edema of the limbs. Tick exposure or tick infestation were commonly observed in all horses.

\section{Samples}

Whole blood was collected aseptically via jugular venipuncture and an aliquot was allowed to clot, then centrifuged and serum was separated. Another part of the sample was EDTA-whole blood that was used as a source for buffy coat smears stained with Giemsa. The remaining blood was stored at $-20{ }^{\circ} \mathrm{C}$ until assayed.

\section{A. phagocytophilum serology}

An enzyme-linked immunosorbent assay (ELISA) for detection of $\mathrm{IgG}$ antibodies against $A$. phagocytophilum was performed (Ehrlichia equi IgG antibody Kit - ELISA - Helica Biosystems, Inc.). Briefly, equine serum samples were diluted to $1: 100$ and allowed to react with E. equi / (A. phagocytophilum) whole antigens coated on specially treated micro-well plates provided with the kit. The reactions were performed according to the manufacter's instructions and the results were based on color intensity (absorbance) developed with an optical density (OD) of $450 \mathrm{~nm}$. The visual determinations were made with aid of the color chart provided by the kit. ODs over 0.32 were interpreted as positive.

\section{Theileria equi serology}

Indirect immnufluorescent antibody assays (IFA) were performed to detect IgG antibodies against T. equi as previously described by Machado et al. (1994), with a serum dilution of 1: 80. Also, an ELISA test was performed as reported elsewhere (BALDANI et al., 2004 ) with an antigen concentration of $10 \mu \mathrm{g} \cdot \mathrm{mL}^{-1}$ and a serum 
dilution of 1:100. The immunological activity of each serum was calculated by determining the sample-to-positive serum ratio $(\mathrm{S} / \mathrm{P})$, considering positive and negative sera as reference. Horses were considered positives when $\mathrm{S} / \mathrm{P}$ values at an optical density of $405 \mathrm{~nm}$ were equal to or greater than 0.278 .

\section{DNA isolation}

DNA was extracted from $200 \mu \mathrm{L}$ of EDTA whole-blood EDTA samples using the QIAamp DNA Blood Mini Kit $\left(\right.$ QIAGEN $\left.^{\mathrm{TM}}\right)$, according to the manufacturer's instructions. Samples from the thirteen horses tested as serologically positive $(\mathrm{OD} \geq 0.32)$ for A. phagocytophilum antibodies by the ELISA Kit were analysed. These horse blood samples ( $\mathrm{n}=13$ ) were then collected before (rest, $\mathrm{n}=13$ ) and after exercise (stress, $\mathrm{n}=13$ ), and were submitted to buffy coat smear preparations stained with Giemsa for microscopic examination, and to PCR amplifications for A. phagocytophilum and Ehrlichia spp. DNA extraction was also performed for the detection of T. equi by nPCR.

\section{PCR amplification}

Each extracted DNA sample was used as a template to amplify a specific amplicon in $50 \mu \mathrm{L}$ reaction mixtures containing $10 \times$ PCR buffer, $\mathrm{MgCl}_{2}$, deoxynucleotide triphosphate (dNTPs) mixture, and DNA Taq polymerase (Invitrogen ${ }^{\mathrm{TM}}$ ), and were carried out with the following specific primers for Ehrlichia spp.: ECC (5' - aga acg aac gct ggc ggc aag cc - $\left.3^{\prime}\right)$ and ECB $\left(5^{\prime}-\right.$ cgt att acc gcg gct gct ggc -3 ) that amplify a fragment of 478 bp (PERSING, 1996; KOCAN et al., 2000), for the $A$. phagocytophilum 16sRNA gene: gE3a (5' - cac atg caa gtc gaa cgg att att c - 3'), gE10R (5' - ttc cgt taa gaa gga tct aat ctc c - 3'), gE2 (5' - ggc agt att aaa agc agc tcc agg - 3') and gE9F (5' - aac gga tta ttc ttt ata gct tgc $\left.\mathrm{t}-3^{\prime}\right)$ that amplify fragments of 932 and 546 bp (MASSUNG et al., 1998), respectively, and for the $A$. phagocytophilum msp2 gene: MSP 465F (5' - tga tgt tgt tac tgg aca ga - 3') and MSP 980R $\left(5^{\prime}\right.$ - cac cta acc ttc ata aga a - 3') that amplifies a 550 bp fragment (CASPERSEN et al., 2002). All the amplification reaction mixtures and the cycling parameters were performed as previously described by the authors cited above. The first (PCR) and nested amplifications (nPCR) were performed in a Gradient cycler model PT-200 (Perkin-Elmer ${ }^{\mathrm{TM}}$ ). In each set of amplifications, both positive and negative controls were included. Amplicons were visualized in $1.5 \%$ Agarose gels stained with Ethidium Bromide under UV-light. All the steps were carried out in separate rooms to minimize contamination.

The nPCR for the diagnosis of T. equi were performed as previously described by Baldani et al. (2008).

\section{Results}

\section{Clinical signs and presence of ticks}

The most common clinical signs found in all tested horses were anemia (pale mucous membranes), fever, anorexia, lethargy and limbs edema. Amblyomma cajennense and Amblyomma spp. were the tick species found in these animals.

\section{Buffy coat smears}

None of the samples examined showed any evidence of Anaplamataceae infection as inclusion bodies and/or morulae structures.

\section{Anaplasma phagocytophilum serology}

Thirteen (65\%) of 20 equine serum samples included in this study showed positive reactions $(\mathrm{OD} \geq 0.32$ ) by the ELISA Kit $\left(\right.$ Helica $\left.^{\mathrm{TM}}\right)$. These 13 positive samples were then collected again (after exercise), as previously described, and tested by PCR and nPCR in two sets: before exercise $(n=13)$ and after exercise $(\mathrm{n}=13)$.

\section{Anaplamataceae agents PCR and $n P C R$}

None of the blood samples tested $(n=26)$ were positive by PCR amplification using primers ECC/ECB for Ehrlichia ssp. Also, the amplifications PCR and nPCR for the A. phagocytophilum 16srRNA gene (Figure 1) and msp2 gene were all negative. All the results are summarized in Table 1.

\section{Theileria equi serology and $n P C R$}

Eighteen ( 90\%) equine serum samples tested were positive by the IFA test (cut off titer $\geq 80$ ) and 19 (95\%) by the ELISA assay for the same agent. T. equi was detected by nPCR in $9(45 \%)$ horses.

\section{Discussion}

In the present study none of the twenty equines with clinical signs demonstrated granulocitic morulae or initial bodies in Giemsa blood smears. Clinical anaplasmosis in horses is probably still underdiagnosed in Brazil, especially those horses taking part in sports and traveling to others regions outside of the country where the disease is endemic. On the other hand, clinical anaplasmosis is similar to those caused by infections with other pathogens such as Babesia caballi, Theileria equi, equine infectious anaemia virus, equine herbevirus, equine arteritis virus and Leptospiraceae. Recently, in Brazil, a spontaneous outbreak of Equine Monocytic Ehrlichiosis (EME) was described, caused by Neorickettsia risticii, affecting horses 1-5 years old in the State of Rio Grande do Sul. The most important clinical sign was profuse acute diarrhea, accompanied by anorexia and depression (COIMBRA et al., 2006).

Acute equine ehrlichiosis is evaluated observing the characteristic inclusion bodies in blood smears as well as clinical signs, but chronic cases are not clinically detected. Also, in acute disease a differential diagnosis pattern should be performed because of the nonspecific clinical signs observed. Diseases such as encephalitis, liver disease, purpura hemorrhagica, equine infectious anemia and equine viral arteritis should be ruled out (MADIGAN; GRIBBLE, 1987). The severity of clinical signs of EGA is a function of the age of the horse and the duration of the illness (MADIGAN, 1993). This 

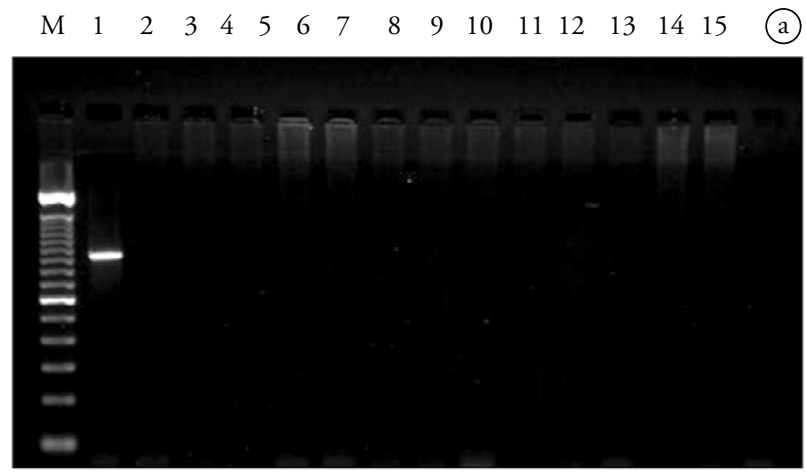

(b)

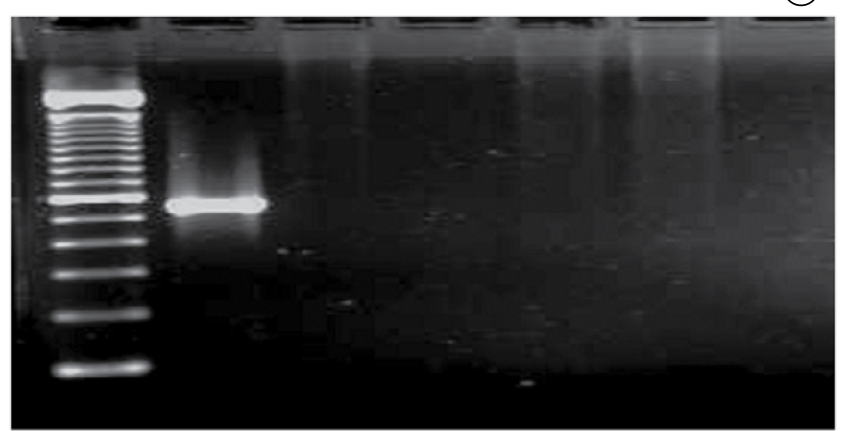

Figure 1. 1,5\% Agarose gel electrophoresis stained with Ethidium Bromide, showing results of equine blood samples tested for $A$. phagocytophila 16SrRNA gene nested PCR ( $\mathrm{a}, \mathrm{b})$ products obtained after amplification with primer pairs gE3a/gE10R; gE2/gE9F (amplicons size 932 and $556 \mathrm{bp}$ ), respectively. a) Lane M: molecular standard size (100 bp); Lane 1, positive control; Lane 2 through 14: horse blood samples and Lane 15, negative control. b) Lane M: molecular standard size; Lane 1, positive control; Lane 2 through 5: horse blood samples and Lane 6, negative control.

Table 1. Results from Buffy coat smear examination, Babesia equi Serology (ELISA and IFA), A. phagocytophilum Serology (ELISA Kit), and PCR/nPCR (16S rRNA gene), PCR (msp2 gene) and Ehrlichia spp. PCR (16S rRNA gene).

\begin{tabular}{|c|c|c|c|c|c|c|c|}
\hline \multirow{2}{*}{$\begin{array}{l}\text { Horse } \\
\text { Sample }\end{array}$} & \multirow{2}{*}{$\begin{array}{l}\text { Buffy coat } \\
\text { smear }\end{array}$} & \multicolumn{2}{|c|}{ Babesia equi } & \multicolumn{3}{|c|}{ Anaplasma phagocytophilum } & \multirow{2}{*}{$\begin{array}{c}\text { Ehrlichia spp. } \\
\text { PCR } \\
\text { 16S rRNA gene }\end{array}$} \\
\hline & & $\begin{array}{l}\text { ELISA } \\
\text { (OD) }\end{array}$ & IFA & $\begin{array}{c}\text { ELISA } \\
\text { kit }\end{array}$ & $\begin{array}{l}\text { PCR/ nPCR } \\
\text { 16S rRNA gene }\end{array}$ & $\begin{array}{c}\text { PCR } \\
\text { msp2 gene }\end{array}$ & \\
\hline 1 & $\mathrm{~N}$ & $\mathrm{~N}(0.175)$ & $\mathrm{N}$ & $\mathrm{P}$ & $\mathrm{N}$ & $\mathrm{N}$ & $\mathrm{N}$ \\
\hline 2 & $\mathrm{~N}$ & $\mathrm{P}(1.207)$ & $\mathrm{P}$ & $\mathrm{P}$ & $\mathrm{N}$ & $\mathrm{N}$ & $\mathrm{N}$ \\
\hline 3 & $\mathrm{~N}$ & $\mathrm{P}(0.952)$ & $\mathrm{P}$ & $\mathrm{P}$ & $\mathrm{N}$ & $\mathrm{N}$ & $\mathrm{N}$ \\
\hline 4 & $\mathrm{~N}$ & $\mathrm{P}(1.082)$ & $\mathrm{P}$ & $\mathrm{P}$ & $\mathrm{N}$ & $\mathrm{N}$ & $\mathrm{N}$ \\
\hline 5 & $\mathrm{~N}$ & $\mathrm{P}(0.919)$ & $\mathrm{P}$ & $\mathrm{P}$ & $\mathrm{N}$ & $\mathrm{N}$ & $\mathrm{N}$ \\
\hline 6 & $\mathrm{~N}$ & $\mathrm{P}(1.620)$ & $\mathrm{P}$ & $\mathrm{P}$ & $\mathrm{N}$ & $\mathrm{N}$ & $\mathrm{N}$ \\
\hline 7 & $\mathrm{~N}$ & $\mathrm{P}(0.859)$ & $\mathrm{P}$ & $\mathrm{P}$ & $\mathrm{N}$ & $\mathrm{N}$ & $\mathrm{N}$ \\
\hline 8 & $\mathrm{~N}$ & $\mathrm{P}(0.784)$ & $\mathrm{P}$ & $\mathrm{P}$ & $\mathrm{N}$ & $\mathrm{N}$ & $\mathrm{N}$ \\
\hline 9 & $\mathrm{~N}$ & $\mathrm{P}(0.909)$ & $\mathrm{P}$ & $\mathrm{P}$ & $\mathrm{N}$ & $\mathrm{N}$ & $\mathrm{N}$ \\
\hline 10 & $\mathrm{~N}$ & $\mathrm{P}(1.311)$ & $\mathrm{P}$ & $\mathrm{P}$ & $\mathrm{N}$ & $\mathrm{N}$ & $\mathrm{N}$ \\
\hline 11 & $\mathrm{~N}$ & $\mathrm{~N}(0.225)$ & $\mathrm{N}$ & $\mathrm{P}$ & $\mathrm{N}$ & $\mathrm{N}$ & $\mathrm{N}$ \\
\hline 12 & $\mathrm{~N}$ & $\mathrm{P}(1.131)$ & $\mathrm{P}$ & $\mathrm{P}$ & $\mathrm{N}$ & $\mathrm{N}$ & $\mathrm{N}$ \\
\hline 13 & $\mathrm{~N}$ & $\mathrm{P}(0.839)$ & $\mathrm{P}$ & $\mathrm{P}$ & $\mathrm{N}$ & $\mathrm{N}$ & $\mathrm{N}$ \\
\hline 14 & NT & P (0.998) & $\mathrm{P}$ & $\mathrm{N}$ & NT & NT & NT \\
\hline 15 & NT & $\mathrm{N}(0.148)$ & $\mathrm{P}$ & $\mathrm{N}$ & NT & NT & NT \\
\hline 16 & NT & $\mathrm{P}(0.901)$ & $\mathrm{P}$ & $\mathrm{N}$ & NT & NT & NT \\
\hline 17 & NT & $\mathrm{P}(0.775)$ & $\mathrm{P}$ & $\mathrm{N}$ & NT & NT & NT \\
\hline 18 & NT & $\mathrm{P}(2.895)$ & $\mathrm{P}$ & $\mathrm{N}$ & NT & NT & NT \\
\hline 19 & NT & $\mathrm{P}(1.323)$ & $\mathrm{P}$ & $\mathrm{N}$ & NT & NT & NT \\
\hline 20 & NT & $\mathrm{P}(0.754)$ & $\mathrm{P}$ & $\mathrm{N}$ & NT & NT & NT \\
\hline
\end{tabular}

$\mathrm{P}=$ positive, $\mathrm{N}=$ negative, $\mathrm{NT}=$ not tested, $\mathrm{OD}=$ optical density.

can make clinical recognition of EGA difficult at the time of the first examination (MADIGAN; GRIBBLE, 1987).

Serum antibodies have been detected by the ELISA Kit $\left(\right.$ Helica $\left.^{\mathrm{TM}}\right)$ in thirteen of 20 equines $(65 \%)$ to $A$. phagocytophilum. The most common serologic diagnostic assay is the detection of serum antibodies by IFA, but the ELISA test has been used to evaluate the response of antibodies to $A$. phagocytophilum in horses (MADIGAN et al., 1990; CORSTVET et al., 1993; MAGNARELLI et al., 2000; 2001; LEBLOND et al., 2005; HANSEN et al., 2010). Also, the IFA tests are a useful tool for diagnosis of EGA convalescence patients (WALLS et al., 1999). Although antibody detection may be of limited value for early serologic diagnosis (van ANDEL et al. 1998), strong serological cross-reactions between all members of the $A$. phagocytophilum have been communicated (DUMLER et al., 1995). Recently, Spolidorio et al. (2010) showed that 25.9\% horses from the State of Espirito Santo, Brazil were reactive to at least one of the six Rickettsia species tested, and in six horses PCR Theileria were detected. It is important to note that no ticks of Ixodes ricinus, a common transmitter of EGA, have been described in Brazil. 
None of the tested animals showed positive reaction in PCR assays to A. phagocytophilum, for either the 16s rRNA gene or $m s p 2$ gene. However, positive nPCR in nine animals to T. equi confirmed the presence of the agent by molecular detection. In addition, $90 \%$ of all animals tested were positive by the IFA test and $95 \%$ by the ELISA assay for the same agent. Previous studies in our laboratory have not confirmed the presence of A. phagocytophilum in blood samples tested from two hundred horses with clinical signs of babesiosis or suspected of anaplasmosis by PCR or nPCR (data not shown). In Brazil, the prevalence of equine piroplasmosis is of serious concern, considered as an endemic disease. To detect anti-T. equi antibodies, Heuchert et al. (1999) tested 752 horse serum samples from São Paulo State, by IFA and a complementary fixation test (CFT), and reported prevalence rates of 29.6 and $17.6 \%$, respectively. Serum samples from horses from different regions of Brazil were tested by CTF and the results demonstrated the prevalence of T. equi infections were $42.48 \%$ (KERBER et al., 1999). Also Xuan et al. (2001) examined serum samples from horses in the State of São Paulo and Mato Grosso do Sul, Brazil, and showed that the positive rate for T. equi was $81 \%$. Baldani et al. (2004) demonstrated that $75 \%$ (67/90) of the horses from the state of Sáo Paulo presented anti-T. equi antibodies by IFA and ELISA tests. The prevalence of equine piroplasmosis reported in the present study is higher and may be due to differences in serological tests used, horse breeding operations, intensity of tick infestation or even number of serum samples examined. This study is the first report on the serological evidence of co-infection with Equine Granulocytic Ehrlichiosis and equine piroplasmosis agents in horses from the Brazilian Army and Goiânia county. Amblyomma cajennense and Amblyomma spp. were the most common tick species found in our animals in this study.

Our data may be considered as important information contributing to understanding the occurrence of these diseases in centralwest Brazil.

\section{Acknowledgments}

We express appreciation to Dr. J. Stephen Dumler for Anaplasma phagocytophilum DNA-positive controls.

\section{References}

AGUERO-ROSENFELD, M. E. et al. Serology of culture-confirmed cases of human granulocytic ehrlichiosis. Journal of Clinical Microbiology, v. 38, n. 2, p. 635-638, 2000.

BAKKEN, J. S. et al. Human Granulocytic Ehrlichiosis in The Upper Midwest United States. A New Species Emerging? The Journal of the American Medical Association, v. 272, n. 3, p. 212-218, 1994.

BALDANI, C. D. et al. An enzyme-linked immunosorbent assay for the detection of IgG antibodies against Babesia equi in horses. Ciência Rural Santa Maria, v. 34, n. 5, p. 1525-1529, 2004.

BALDANI, C. D. et al. In vitro culture, PCR, and nested PCR for the detection of Theileria equi in horses submitted to exercise. Arquivo
Brasileiro de Medicina Veterinária e Zootecnia, v. 60, n. 3, p. 550-558, 2008.

CALIC, S. B. et al. Human ehrlichioses in Brazil: first suspect cases. Brazilian Journal of Infectious Diseases, v. 8, n. 3, p. 259-262, 2004.

CASPERSEN, K. et al. Genetic variability and stability of Anaplasma phagocytophila msp2 ( $p 44)$. Infection and Immunity, v. 70, n. 3, p. 1230-1234, 2002.

COIMBRA, H. S. et al. Ehrlichiose monocítica eqüina no Rio Grande do Sul: aspectos clínicos, anátomo-patológicos e epidemiológicos. Pesquisa Veterinária Brasileira, v. 26, n. 2, p. 97-101, 2006.

CORSTVET, R. E. et al. Detection of humoral antigen and antibody by enzyme-linked immunosorbent assay in horses with experimentally induced Ehrlichia equi infection. Journal of Veterinary Diagnostic Investigation, v. 5, n. 1, p. 37-39, 1993.

DUMLER, J. S. et al. Serologic cross-reactions among Ehrlichia equi, Ehrlichia phagocytophila, and human granulocytic Ehrlichia. Journal of Clinical Microbiology, v. 33, n. 5, p. 1098-1103, 1995.

DUMLER, J. S. et al. Reorganization of genera in the families Rickettsiaceae and Anaplasmataceae in the order Rickettsiales: unification of some species of Ehrlichia with Anaplasma, Cowdria with Ehrlichia and Ehrlichia with Neorickettsia, descriptions of six new species combinations and designation of Ehrlichia equi and 'HGE agent' as subjective synonyms of Ehrlichia phagocytophila. International Journal of Systematic and Evolutionary Microbiology, v. 51, n. 6, p. 2145-2165, 2001.

FOLEY, J. E. et al. Ecology of Anaplasma phagocytophilum and Borrelia burgdorferi in the western United States. Journal of Vector Ecology, v. 29, n. 1, p. 41-50, 2004.

GOODMAN, J. L. et al. Direct cultivation of the causative agent of Human Granulocytic Ehrlichiosis. The New England Journal of Medicine, v. 334, n. 4, p. 209-215, 1996.

GRIBBLE, D. H. Equine Ehrlichiosis. Journal of the American Veterinary Medical Association, v. 155, n. 2, p. 462-469, 1969.

HANSEN, M. G. et al. Seroprevalence of Borrelia burgdorferi sensu lato and Anaplasma phagocytophilum in Danish horses. Acta Veterinaria Scandinavica, v. 52, n. 3, 2010.

HEO, E-J. et al. Serologic and molecular detection of Ehrlichia chaffeensis and Anaplasma phagocytophila (Human Granulocytic Ehrlichiosis agent) in Korean patients. Journal of Clinical Microbiology, v. 40 n. 8, p. 3082-3085, 2002.

HEUCHERT, C. M. S. et al. Seroepidemiologic studies on Babesia equi and Babesia caballi infections in Brazil. Veterinary Parasitology, v. 85, n. 1, p. 1-11, 1999.

JOHANSSON, K. E. et al. Identification of the causative agent of granulocytic ehrlichiosis in Swedish dogs and horses by direct solid phase sequencing of PCR products from 16S rRNA gene. Research in Veterinary Science, v. 58, n. 2, p. 109-112, 1995.

KERBER, C. E.; FERREIRA, F; PEREIRA, M. C. Control of equine piroplasmosis in Brazil. Onderstepoort Journal of Veterinary Research, v. 66 , n. 2, p. 123-127, 1999.

KOCAN, A. et al. Naturally occurring Ehrlichia chaffeensis infection in coyotes from Oklahoma. Emerging Infectious Diseases, v. 6, n. 5, p. 477-480, 2000. 
LEBLOND, A. et al. An epidemiological survey of equine anaplasmosis (Anaplasma phagocytophilum) in southern France]. Revue Scientific et Technique, v. 24, n. 3, p. 899-908, 2005.

LÓPEZ, J. et al. Serologic evidence for human Ehrlichiosis in Chile. Revista Médica de Chile, v. 131, n. 1, p. 67-70, 2003.

MACHADO, R. Z. et al. Detection of Ehrlichia chaffeensis in Brazilian marsh deer (Blastocerus dichotomus). Veterinary Parasitology, v. 139, n. 1-3, p. 262-266, 2006.

MACHADO, R. Z. et al. Isolation of Babesia bigemina and Babesia bovis merozoites by ammonium chloride lysis of infected erytrocytes. Brazilian Journal of Medical and Biological Research, v. 27, n. 11, p. 2591-2598, 1994.

MADIGAN, J. E. Equine Ehrlichiosis. Veterinary Clinics of North America. Equine Practice, v. 9, n. 2, p. 423-428, 1993.

MADIGAN, J. E.; GRIBBLE, D. Equine ehrlichiosis in northern California: 49 cases (1968-1981). Journal of the American Veterinary Medical Association, v. 190, n. 4, p. 445-448, 1987.

MADIGAN, J. E. et al. Seroepidemiologic survey of antibodies to Ehrlichia equi in horses of northern California. Journal of the American Veterinary Medical Association, v. 196, n. 12, p. 1962-1964, 1990.

MAGNARELLI, L. A. et al. Evaluation of a polyvalent enzyme-linked immunosorbent assay incorporating a recombinant p44 antigen for diagnosis of granulocytic ehrlichiosis in dogs and horses. American Journal of Veterinary Research, v. 62, n. 1, p. 29-32, 2001.

MAGNARELLI, L. A. et al. Serologic confirmation of Ehrlichia equi and Borrelia burgdorferi infections in horses from the northeastern United States. Journal of the American Veterinary Medical Association, v. 17, n. 7, p. $1045-1050,2000$.

MASSUNG, R. F.; SLATER, K. G. Comparasion of PCR assays for detection of the agent of human granulocytic ehrlichiosis, Anaplasma phagocytophilum. Journal of Clinical Microbiology, v. 41, n. 2, p. 717-722, 2003.

MASSUNG, R. F. et al. Nested PCR assay for detection of Granulocytic Ehrlichiae. Journal of Clinical Microbiology, v. 36, n. 4, p. 1090-1095, 1998.
PANCHOLI, P. et al. Ixodes dammini as a Potential Vector of Human Granulocytic Ehrlichiosis. Journal of Infectious Diseases, v. 172, n. 4, p. 1007-1012, 1995.

PEREZ, M. et al. Human infection with Ehrlichia canis accompanied by clinical signs in Venezuela. Annals of the New York Academy of Sciences, v. 1078, p. 110-117, 2006.

PERSING, D. H. PCR Protocols for Emerging Infectious Diseases. A supplement to Diagnostic Molecular Microbiology: Principles and Applications. Washington, D.C.: ASM Press, 1996.

RIKIHISA, Y. Mechanisms to create a safe haven by members of the Family Anaplasmataceae. Annals of the New York Academy of Sciences, v. 990, p. 548-555, 2003.

RIKIHISA, Y. The Tribe Ehrlichieae and Ehrlichial Diseases. Clinical Microbiology Reviews, v. 4, n. 3, p. 286-308, 1991.

RIPOLL, C. M. et al. Evidence of rickettsial spotted fever and ehrlichial infections in a subtropical territory of Jujuy, Argentina. The American Journal of Tropical Medicine and Hygiene, v. 61, n. 2, p. 350-354, 1999.

RUSCIO, M.; CINCO, M. Human granulocytic ehrlichiosis in Italy. Annals of the New York Academy of Sciences, v. 990, p. 350-352, 2003.

SPOLIDORIO, M. G. et al. Survey for Tick-Borne zoonoses in the state of Espirito Santo, Southeastern Brazil. The American Society of Tropical Medicine and Hygiene, v. 83, n. 1, p. 201-206, 2010.

STANNARD, A. A.; GRIBBLE, D. H.; SMITH, R. S. Equine ehrlichiosis: a disease with similarities to tick-borne fever and bovine petechial fever. Veterinary Record, v. 84, n. 6, p. 149-150, 1969.

van ANDEL, A. E. et al. Development and duration of antibody response against Ehrlichia equi in horses. Journal of the American Veterinary Medical Association, v. 212, n. 12, p. 1910-1914, 1998.

WALLS, J. J. et al. Inter- and Intralaboratory comparison of Ehrlichia equi and Human Granulocytic Ehrlichiosis (HGE) Agent Strains for serodiagnosis of HGE by the Immunofluorescent-antibody test. Journal of Clinical Microbiology, v. 37, n. 9, p. 2968-2973, 1999.

XUAN, X. et al. Diagnosis of equine piroplasmosis in Brazil by serodiagnostic methods with recombinant antigens. Journal of Veterinary Medical Science, v. 63, n. 10, p. 1159-1160, 2001. 